\title{
From Targets to Treatments: A Review of Molecular Targets in Pancreatic Neuroendocrine Tumors
}

\author{
Bertram Wiedenmann ${ }^{a}$ Marianne Pavel ${ }^{a}$ Beata Kos-Kudla ${ }^{b}$ \\ a Department of Hepatology, Gastroenterology and Endocrinology, Charité Medical School, Berlin, Germany; \\ ${ }^{b}$ Department of Pathophysiology and Endocrinology, Silesian Medical University, Katowice, Poland
}

\section{Key Words}

Molecular targets - Pancreatic neuroendocrine tumors •

Targeted therapies

\begin{abstract}
Pancreatic neuroendocrine tumors (pancreatic NET) are relatively rare, slowly growing tumors, although their incidence is increasing, and patients may survive for several years with metastatic disease. Apart from symptomatic relief, there have been few treatment options for these tumors in the past. More recently, investigators have explored the potential of molecularly targeted agents in treating pancreatic NET, with some success. In this review, we consider the data supporting exploitation of different targets in pancreatic $\mathrm{NET}$, including peptide receptors, receptor tyrosine kinases (involved in tumor angiogenesis and more directly supporting tumor growth), and intracellular targets, such as the mammalian target of rapamycin (mTOR), which has a central role in regulating cell growth, metabolism, and apoptosis. Probably due to the paucity of pancreatic NET, many clinical trials to date have included heterogeneous NET populations, and there are few randomized studies of this specific patient population. Very recently, promising results have been achieved in placebo-controlled, phase III trials with the multitargeted tyrosine kinase inhibitor, sunitinib, and the mTOR inhibitor, everolimus. These agents have been approved or
\end{abstract}

\section{KARGER}

Fax +4161306 1234

E-Mail karger@karger.ch

www.karger.com (c) 2011 S. Karger AG, Basel

0028-3835/11/0943-0177\$38.00/0

Accessible online at:

www.karger.com/nen are currently being reviewed by authorities for use in patients with pancreatic NET. Here we review potential molecular targets in pancreatic NET and summarize the available data for targeted agents from phase II and III trials open to patients with this tumor.

Copyright $\odot 2011$ S. Karger AG, Basel

\section{Introduction}

Pancreatic neuroendocrine tumors (pancreatic NET) are increasing in incidence $[1,2]$ and, with improved diagnostics and better recognition within the medical community, their prevalence is higher than previously thought [3]. The natural course of the disease varies according to the type of primary tumor, tumor size, and histological grade. Symptoms arising from hypersecretion of hormones or amines occur in less than half of all cases. The lack of specific symptoms in nonfunctional tumors leads to an often higher tumor mass at first presentation compared with their functional counterparts. Approximately two thirds of patients with pancreatic NET have distant metastases at diagnosis [1].

Recent years have seen a dramatic increase in the number of molecularly targeted agents to treat cancer as a result of our increased understanding of the processes and pathways involved in tumorigenesis. This paper fo- 
Fig. 1. Schematic diagram of a theoretical pancreatic endocrine tumor cell, smooth muscle cell (pericyte) or endothelial cell demonstrating the sites and mechanism of action of novel agents for the management of metastatic pancreatic neuroendocrine tumors. Adapted from Metz and Jensen [4], copyright permission obtained.

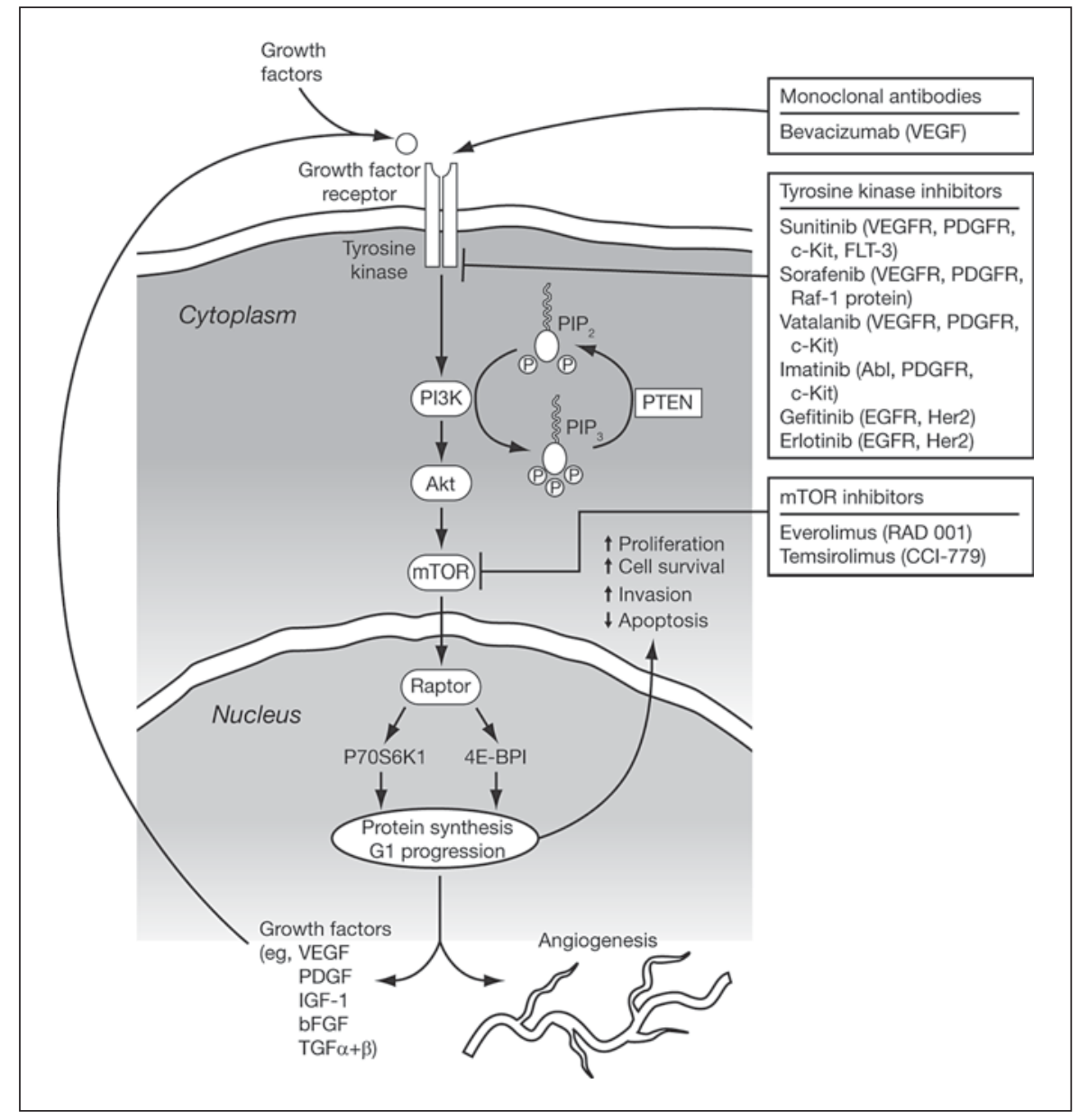

cuses on molecules identified as potential treatment targets in pancreatic NET and reviews the latest data on experimental antitumor agents acting at these targets.

\section{Molecular Targets in Pancreatic NET}

A number of potential therapeutic targets have been identified and are currently under investigation for treating pancreatic NET (fig. 1) [4].

\section{Peptide Receptors}

The first 'targeted' treatments for pancreatic and other types of NET were somatostatin analogs, used since the 1980 s to alleviate symptoms of hormonal hypersecretion. Somatostatin analogs are still a key component of treatment today, and further exploration of the somatostatin receptors (SSTRs) as relevant targets has yielded new approaches to diagnosis and treatment.
Somatostatin and Its Receptors

Somatostatin, an endogenous cyclic peptide, regulates the secretion of growth hormone, insulin, glucagon and gastrin [5]. It acts through a family of seven G proteincoupled transmembrane receptors with five distinct subtypes (SSTR1-5) [6, 7]. Activation of SSTRs has a variety of direct and indirect effects [8]. Direct antiproliferative effects include inhibition of the cell cycle, inhibition of growth factor effects, and induction of apoptosis. The literature suggests that these effects may be mediated by the PI3K/mammalian target of rapamycin (mTOR), mitogen-activated protein kinase (MAPK), and Ras/extracellular signal-regulated kinase (ERK) signaling pathways $[9,10]$. Indirect effects include inhibition of the release of growth factors and trophic hormones, inhibition of angiogenesis, and modulation of the immune system [8]. Studies of receptor distribution in different types of pancreatic NET show that receptor expression is widespread (50-100\% of tumor samples across different stud- 
ies), with more than one subtype commonly expressed in a given tumor [11-14]. However, expression appears to vary with histological type, as well as between patients with the same tumor type. Nevertheless, expression of SSTR2 and SSTR5 is found in approximately 90 and $80 \%$ of pancreatic NET tumor cells, respectively, and pancreatic NET is potentially sensitive to hormone treatment [15]. Somatostatin itself has a very short half-life $(\sim 3-4$ min) [7]. Attempts have therefore been made to synthesize somatostatin analogues such as octreotide and lanreotide that have high affinity to SSTR 2 and SSTR 5 but lack the disadvantages associated with somatostatin [7, 16].

\section{Other Peptide Receptors}

Successful exploitation of the SSTR for both diagnostic and therapeutic purposes in managing pancreatic NET has led to increased interest in the distribution of other peptide receptors. The limited evidence available suggests that receptors for bombesin, cholecystokinin, and vasoactive intestinal peptide are all expressed to some degree on at least some types of pancreatic NET [17-21].

\section{Receptor Tyrosine Kinases and Angiogenic Mediators}

Angiogenesis is a central and complex process in tumor growth and metastasis, and involves a number of receptor tyrosine kinases (RTKs) and their ligands. The importance of angiogenesis in the development of pancreatic NET is supported by studies in the RIP1-Tag2 mouse model $[22,23]$, discussed in more depth below.

Vascular Endothelial Growth Factor Receptor

Both vascular endothelial growth factor (VEGF)-A and its receptors, VEGFR-1 and VEGFR-2, are constitutively expressed in normal islets as well as in pancreatic RIP1-Tag2 tumors [24]. Using the same model, VEGF-A was shown to be critical for the angiogenic switch, as well as for tumor growth [25]. Inhibitors of VEGFR significantly reduce pancreatic tumor growth or cause regression of established tumors in treated mice, compared with controls, and also disrupt tumor vasculature [2630].

Several studies have investigated the expression of VEGF, VEGFR, and other markers of angiogenesis in tumor biopsy samples from patients with pancreatic NET (table 1). Taken together, the studies suggest that VEGF may be only weakly expressed in many pancreatic NET, but is strongly expressed in at least some cases. There are conflicting data on whether VEGF expression is highest in benign tumors [31, 32] or (specifically VEGF-C expression) in well differentiated neuroendocrine carcinomas $[33,34]$, and on whether or not microvascular density (MVD) is correlated with VEGF expression [31-34].

In a single study, expression of VEGFR-2 and VEGFR-3 in neoplastic cells was variable, but (in a preliminary comparison) was possibly correlated with ligand expression in both primary and metastatic tissue, suggesting that VEGFR may be involved in regulating growth or survival of some pancreatic NET [33].

\section{Angiopoietin-2}

A recent study reported high uniform expression of Angiopoietin-2 (Ang-2) messenger RNA (mRNA) in endothelial cells of both nontransformed pancreatic tissue and pancreatic NET tissue [35]. Interestingly, epithelial mRNA Ang-2 expression occurred exclusively in pancreatic NET cells. Increased microvessel density and enhanced lymphatic metastasis were evident in Ang-2-expressing tumors, indicating a functional role of Ang- 2 in experimental NET. Consistent with this notion, circulating Ang-2 was significantly elevated in patients with NET, compared with healthy controls. Furthermore, elevated Ang-2 levels were correlated with presence of metastatic disease, with the highest concentrations found in patients with liver metastasis. Ang-2 concentrations above the 75th percentile predicted shorter survival $(\mathrm{p}=0.0003)$. These findings are supported by other studies of patients with NET $[36,37]$. Significantly elevated levels of serum Ang-2 levels $(p=0.01)$ were found in patients with NET ( $\mathrm{n}=47 ; 17$ with pancreatic NET), compared with healthy controls $(n=44)$, and the time to disease progression was shorter in those patients with serum Ang-2 levels above $4,756 \mathrm{pg} / \mathrm{ml}(\mathrm{p}=0.04)$ [37]. The induction of Ang-2 in pancreatic NET may, therefore, represent a clinically relevant mechanism of disease progression and could constitute an adverse prognostic marker [35].

\section{Platelet-Derived Growth Factor Receptor}

In a single series of human pancreatic NET samples, both platelet-derived growth factor receptor (PDGFR)- $\alpha$ and PDGFR- $\beta$ were commonly expressed in primary and metastatic tumor cells, as well as tumor stroma [38]. PDGFR- $\beta$ expression was upregulated in primary pancreatic NET and metastases compared with normal endocrine pancreatic tissue, and in tumor stroma compared with normal pancreatic stroma [39]. In a gene profiling study, PDGFR- $\beta$ was upregulated in pancreatic neuroen- 
Table 1. Summary of published studies investigating the expression of VEGF, VEGFR, and microvascular density in tumor biopsy samples from patients with pancreatic NET

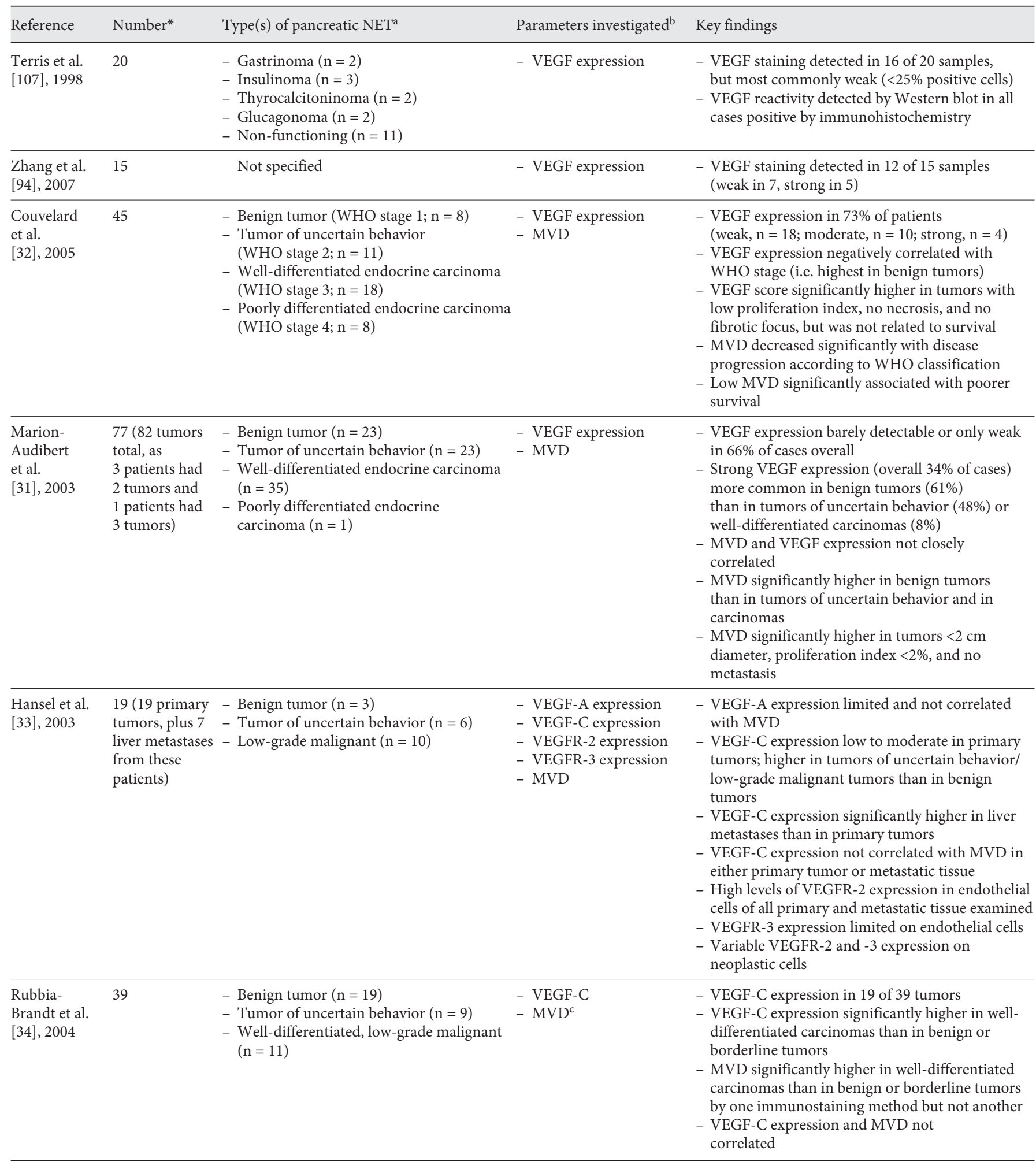

${ }^{*}$ Number of patients with pancreatic NET in series. ${ }^{a}$ Classification cited as in publication. ${ }^{b}$ Not necessarily a comprehensive list for each reference: relevant parameters only (i.e. VEGF, VEGFR or MVD) included in this table. ${ }^{c}$ Lymphatic vessel density. 
docrine carcinomas with metastases compared with benign pancreatic NET [40].

Inhibitors of PDGFR significantly reduce tumor growth or cause regression of established pancreatic tumors in treated mice compared with controls, and also disrupt tumor vasculature $[26,27,29,30]$.

\section{Stem Cell Factor Receptor (c-Kit)}

Several studies have demonstrated expression of c-kit in human pancreatic NET tissue samples [38, 41-43]. The proportion of positive samples ranged widely from approximately $14-90 \%$ between reports, and within one study varied substantially with the type of antibody used to detect c-kit [41]. Inconsistencies between studies may therefore be related to technique rather than necessarily reflecting a real variation in c-kit levels. Recently, c-kit expression has been identified as an independent prognostic marker for pancreatic NET [44].

\section{Epidermal Growth Factor Receptor}

Several immunohistochemical studies have reported epidermal growth factor receptor (EGFR) expression in human pancreatic NET samples [38, 45-49]. Estimates of the proportion of samples expressing EGFR range from 18 to $65 \%$, with variation in the intensity of staining also reported. The variation between studies may reflect differences in the patient populations or antibodies used [48]. Although there is some debate as to whether EGFR expression can be used as a marker of malignancy in NET $[46,50]$, a recent study found that the expression of EGFR correlated significantly with the grade of malignancy in pancreatic NET, increasing from low levels of expression in benign tumors and those of uncertain behavior to high levels of expression in welland poorly differentiated tumors [49]. Furthermore, patients with pancreatic NET expressing activated EGFR have been found to have significantly worse prognosis than those with tumors not expressing activated EGFR [48]. Targeted therapy against the EGFR tyrosine kinase domain may therefore prove to be a useful therapeutic approach for pancreatic NET.

\section{Sarcoma Kinase}

Sarcoma (Src) family kinase activity has been shown to regulate adhesion, spreading, and migration of pancreatic NET cells in vitro [51]. The Src-like kinase, LCK (lymphocyte-specific protein tyrosine kinase), was found to be significantly upregulated at the RNA level in both primary and metastatic pancreatic NET compared with normal islets, with a 4.35 -fold difference $(p=0.02)$ [52].
Immunohistochemical findings also supported the upregulation of LCK. However, there was no significant correlation between LCK staining and stage, differentiation, proliferation, functional status, or clinical outcome.

\section{Combining Angiogenic Targets}

The pathways involved in angiogenesis are heavily interlinked. For example, dual inhibition of VEGFR and PDGFR results in a greater antiangiogenic effect in the RIP1-Tag2 model than selective inhibition of VEGFR or PDGFR alone, with substantial decreases in both endothelial cells and pericytes [53]. A therapeutic approach combining several targeted agents or using a single, multitargeted agent, may therefore be of greater value than using an agent directed at a single target alone.

\section{Intracellular and Downstream Targets}

Targeting intracellular molecules, such as those mediating signal transduction downstream of RTKs, offers yet another potential therapeutic approach. One established target is mTOR, a serine/threonine kinase with a central role in regulating cell growth, metabolism, and apoptosis.

mTOR

Mutations in specific tumor suppressor genes known to regulate mTOR appear to be associated with an increased risk of developing pancreatic NET. These regulatory genes include, most notably, phosphatase and tensin homolog (PTEN) [54, 55], the tuberous sclerosis complex 2 gene (TSC2) [56-58] and, possibly, neurofibromatosis type $1[59,60]$. In a recent gene expression profiling study using a large panel of pancreatic NET, PTEN and TSC2 were downregulated in most primary tumors examined [61]. Downregulation was significantly associated with shorter disease-free and overall survival (OS), supporting a role for the PI3K/Akt/mTOR pathway in the development of pancreatic NET.

\section{Other Potential Targets}

Several additional potential therapeutic targets have been identified by research into pancreatic NET. Expression of these targets is summarized and referenced in table 2 . One target worth more detailed discussion is the dopamine receptor; targeting this receptor is showing potential in treating other tumors and may be of benefit in NET.

\section{Dopamine Receptors}

Dopaminergic drugs have been shown to inhibit human small-cell lung cancer growth both in vivo and in vi- 
Table 2. Additional potential therapeutic targets in pancreatic neuroendocrine tumors

\begin{tabular}{|c|c|c|c|}
\hline \multirow[t]{2}{*}{ Target } & \multicolumn{3}{|c|}{ Target expression and/or antitumor efficacy of drug directed at target shown in: } \\
\hline & cell lines in vitro & animal model & human tumor samples \\
\hline $\begin{array}{l}\text { IGF system (including IGF-1; } \\
\text { IGF-2; IGF-1R; IGF-2R; and IGF- } \\
\text { binding proteins) }\end{array}$ & $\begin{array}{l}\text { Antiproliferative effects of IGF-1R } \\
\text { inhibitor [108] }\end{array}$ & IGF-1R upregulated [109] & $\begin{array}{l}\text { mRNA expression upregulated [110, } \\
111] \text {; } \\
\text { increased IGF- } 1 \text { mRNA correlated with } \\
\text { tumor growth/aggressiveness [111] }\end{array}$ \\
\hline B-Raf & $\begin{array}{l}\text { Inhibition of downstream signaling and } \\
\text { anti-proliferative effects by B-raf inhibitor } \\
\text { (sorafenib) [112] }\end{array}$ & Not evaluated & Protein expression upregulated [112] \\
\hline Cyclooxygenase 2 (COX-2) & $\begin{array}{l}\text { Significant, dose-dependent reduction } \\
\text { of cell viability associated with increased } \\
\text { apoptosis in BON cells and mouse } \\
\text { insulinoma } \beta \text { TC-3 [49] }\end{array}$ & Not evaluated & $\begin{array}{l}\text { Protein expression upregulated } \\
{[113,114] \text {; may be linked to tumor }} \\
\text { progression }[113]\end{array}$ \\
\hline $\begin{array}{l}\text { Metastasis-associated gene } 1 \\
(\text { MTA-1) }\end{array}$ & Not evaluated & Not evaluated & $\begin{array}{l}\text { Expression associated with malignant } \\
\text { behavior [115] }\end{array}$ \\
\hline Histone deacetylase (HDAC) & $\begin{array}{l}\text { Antiproliferative effects of HDAC } \\
\text { inhibitor }[116,117]\end{array}$ & Not evaluated & Not evaluated \\
\hline $\begin{array}{l}\text { Cyclin-dependent kinase } 4 \\
\text { (CDK4) }\end{array}$ & Not evaluated & Not evaluated & $\begin{array}{l}\text { Protein and mRNA expression } \\
\text { upregulated [118] }\end{array}$ \\
\hline Claudin 3 and 7 & Not evaluated & Not evaluated & $\begin{array}{l}\text { Protein and mRNA expression } \\
\text { upregulated [119] }\end{array}$ \\
\hline $\begin{array}{l}\text { MAGE1 (target antigen for auto- } \\
\text { logous cytotoxic T lymphocytes) }\end{array}$ & Not evaluated & Not evaluated & Protein expression upregulated [120] \\
\hline $\begin{array}{l}\text { p53 pathway and its negative regu- } \\
\text { lators MDM2, MDM4, and WIP1 }\end{array}$ & $\begin{array}{l}\text { MDM2 gene amplification, } \\
\text { increased mRNA and protein levels [121] }\end{array}$ & Not evaluated & $\begin{array}{l}\text { MDM2, MDM4 and/or WIP1 gene } \\
\text { amplification [121] }\end{array}$ \\
\hline PI3K/Akt & $\begin{array}{l}\text { Antiproliferative effects of PI } 3 \mathrm{~K} \text { and Akt } \\
\text { inhibitors in BON cells, with decreased } \\
\text { levels of phosphorylated Akt [122] }\end{array}$ & Not evaluated & Activated Akt detected [123] \\
\hline $\begin{array}{l}\text { D114/Notch and Ephrin-B2/ } \\
\text { EphB4 pathways }\end{array}$ & Not evaluated & $\begin{array}{l}\text { In the RIP1-Tag2 model, } \\
\text { inhibition of D114/EphB4 } \\
\text { disrupted tumor angiogenesis } \\
\text { and reduced tumor size [124] }\end{array}$ & Not evaluated \\
\hline
\end{tabular}

tro [62], and it has been proposed that they may also have an antiproliferative effect in secreting pancreatic NET [63]. Several studies have investigated dopamine 2 expression in NETs [64-67]. Grossrubatscher et al. [65] showed high expression of these receptors in $85 \%$ of NET tumors studied; most tumors were located in the pancreas $(n=15)$ and the lung $(\mathrm{n}=14)$. Dopamine 2 receptor immunoreactivity was present in $93 \%$ of the islet cell tumors studied. Generally, high positivity was reported in more than $70 \%$ of tumor cells, particularly in bronchial and pancreatic tumors. The authors conclude that there may be a role for dopaminergic drugs in inhibiting secretion and/or cell proliferation in NETs. Interestingly, co-expression of the dopamine 2 receptors with SSTR2 and SSTR5 has also been found, with higher expression of the dopamine receptors in low-grade rather than high-grade NET [67]. Kidd et al. [68] report variable expression of dopamine 2 and somatostatin receptors depending on cell type and tissue of origin, with differential cytotoxicity induced by chimeric compounds. A somatostatin/dopamine chimeric compound may therefore be a viable therapeutic option.

\section{Progress in Pancreatic NET Using Molecularly \\ Targeted Therapies}

This section focuses on agents in phase II or later development (table 3). The clinical data are notable for their heterogeneity with respect to the enrolled patient population and for the current lack of randomized trials, stemming in part from the rarity of the tumors. 
Table 3. Summary of targeted agents with phase II or III clinical data that include patients with pancreatic NET

\begin{tabular}{|c|c|c|c|c|c|}
\hline Agent $^{\mathrm{a}}$ & Target(s) & $\begin{array}{l}\text { Clinical } \\
\text { development phase }\end{array}$ & $\begin{array}{l}\text { Population }{ }^{\mathrm{b}} \\
\text { (n patients total) }\end{array}$ & Outcomes & References \\
\hline $\begin{array}{l}{ }^{177} \text { LU- } \\
\text { DOTATATE }\end{array}$ & $\begin{array}{l}\text { Somatostatin } \\
\text { receptors }\end{array}$ & II & $\begin{array}{l}\text { Mixed gastroenteropancreatic NET, } \\
\text { retrospective analysis } \\
\text { ( } \mathrm{n}=310 ; 72 \text { with nonfunctioning } \\
\text { pancreatic NET; } 12 \text { with gastri- } \\
\text { noma; } 5 \text { with insulinoma; } \\
2 \text { with VIPoma) }\end{array}$ & $\begin{array}{l}\text { Study population } 21 \% \text { CR; } 28 \% \text { PR; } \\
\text { median TTP = } 40 \text { months in a mixed } \\
\text { patient population, prior tumor } \\
\text { progression not required; median OS } \\
\text { from start of treatment = } 46 \text { months } \\
\text { Nonfunctioning pancreatic NET } \\
(\mathrm{n}=72): 6 \% \text { CR; } 36 \% \text { PR; } 18 \% \text { MR; } \\
26 \% \text { SD; } 14 \% \text { PD } \\
\text { Gastrinoma }(n=12): 5 \text { PR; } 4 \text { MR; } \\
2 \text { SD; } 1 \text { PD } \\
\text { Insulinoma }(n=5): 3 \text { PR; } 1 \text { SD; } 1 \text { PD } \\
\text { VIPoma }(n=2): 1 \text { PR; } 1 \text { PD }\end{array}$ & $\begin{array}{l}\text { Kwekkeboom et al. } \\
{[84], 2008}\end{array}$ \\
\hline Sunitinib & $\begin{array}{l}\text { VEGFR-1-3, } \\
\text { PDGFR- } \alpha \text { and } \\
-\beta, c-k i t, \text { RET, } \\
\text { CSF-1R, FLT3 }\end{array}$ & III (vs. placebo) & $\begin{array}{l}\text { Well-differentiated pancreatic NET } \\
(\mathrm{n}=171 ; 86 \text { received sunitinib) } \\
\text { Advanced carcinoid }(\mathrm{n}=41) \text { and } \\
\text { pancreatic NET }(\mathrm{n}=66)\end{array}$ & $\begin{array}{l}\text { Pancreatic NET: median PFS }=11.4 \\
\text { vs. } 5.5 \text { months with placebo; } \\
\text { ORR }=9.3 \text { vs. } 0 \% \text { with placebo } \\
\text { Pancreatic NET: median TTP }=7.7 \\
\text { months; } 1 \text {-year survival }=81.1 \% ; \\
\text { ORR }=16.7 \% ; \text { SD }=68 \%\end{array}$ & $\begin{array}{l}\text { Raymond et al. [86], } \\
2011 \\
\text { Kulke et al. [85], } \\
2008\end{array}$ \\
\hline Sorafenib & $\begin{array}{l}\text { VEGFR-2-3, } \\
\text { PDGFR- } \beta \text {, } \\
\text { FLT3, c-kit, RET }\end{array}$ & II & $\begin{array}{l}\text { Two cohorts: pancreatic NET and } \\
\text { gastrointestinal NET }(n=93 ; 43 \\
\text { with pancreatic NET) }\end{array}$ & $\begin{array}{l}\text { Pancreatic NET: ORR }=10 \% \\
61 \% \mathrm{PF} \text { at } 6 \text { months }\end{array}$ & $\begin{array}{l}\text { Hobday et al. [87], } \\
2007\end{array}$ \\
\hline Vatalanib & $\begin{array}{l}\text { VEGFR-1-3, } \\
\text { PDGFR- } \beta \text {, c-kit }\end{array}$ & II & $\begin{array}{l}\text { Mixed NET } \\
(n=20 ; 4 \text { with pancreatic NET) }\end{array}$ & $\begin{array}{l}\text { Study population: } 50 \% \text { SD at } 6 \\
\text { months; median TTP }=7 \text { months }\end{array}$ & $\begin{array}{l}\text { Pavel et al. [89], } \\
2008\end{array}$ \\
\hline Imatinib & $\begin{array}{l}\text { PDGFR- } \alpha \text { and } \\
-\beta, \text { BCR-ABL, } \\
\text { c-kit }\end{array}$ & II & $\begin{array}{l}\text { Mixed NET } \\
(\mathrm{n}=15 ; 1 \text { with pancreatic NET })\end{array}$ & Pancreatic NET: PD in 1 patient & $\begin{array}{l}\text { Gross et al. [90], } \\
2006\end{array}$ \\
\hline Gefitinib & EGFR & II & $\begin{array}{l}\text { Two cohorts: pancreatic and } \\
\text { gastrointestinal NET } \\
(\mathrm{n}=96 ; 39 \text { with pancreatic NET) }\end{array}$ & $\begin{array}{l}\text { Pancreatic NET: } 31 \% \text { PF at } 6 \text { months; } \\
7 \% \text { PR; } 14 \% \text { SD }\end{array}$ & $\begin{array}{l}\text { Hobday et al. [93], } \\
2006\end{array}$ \\
\hline Bevacizumab & $\begin{array}{l}\text { VEGF } \\
\text { (all biologically } \\
\text { active forms) }\end{array}$ & $\begin{array}{l}\text { II (+ temozolomide) } \\
\text { II (+ FOLFOX) } \\
\text { II (+ capecitabine + } \\
\text { oxaliplatin) }\end{array}$ & $\begin{array}{l}\text { Pancreatic or gastrointestinal NET } \\
(\mathrm{n}=34 ; 18 \text { with pancreatic NET) } \\
\text { Mixed NET } \\
(\mathrm{n}=13 ; 6 \text { with pancreatic NET) } \\
\text { Mixed NET ( } \mathrm{n}=13 \text {; number of } \\
\text { patients with pancreatic NET not } \\
\text { reported) }\end{array}$ & $\begin{array}{l}\text { Pancreatic NET: } 24 \% \text { PR; } 70 \% \text { SD } \\
\text { Pancreatic NET: } 33 \% \text { PR; } 67 \% \text { SD } \\
\text { Study population: } 31 \% \text { PR; } 46 \% \text { SD } \\
\text { No specific pancreatic data }\end{array}$ & $\begin{array}{l}\text { Kulke et al. [95], } \\
2006 \\
\text { Venook et al. [97], } \\
2008 \\
\text { Kunz et al. [98], } \\
2010\end{array}$ \\
\hline \multirow[t]{3}{*}{ Everolimus } & \multirow[t]{3}{*}{ mTOR } & II (+ octreotide) & $\begin{array}{l}\text { Mixed NET } \\
(\mathrm{n}=60 ; 30 \text { with pancreatic NET })\end{array}$ & $\begin{array}{l}\text { Pancreatic NET: } 27 \% \text { PR; } 60 \% \text { SD; } 13 \% \\
\text { PD; median PFS = } 50 \text { weeks; } \\
\text { OS NR }\end{array}$ & $\begin{array}{l}\text { Yao et al. [102], } \\
2008 \mathrm{~b}\end{array}$ \\
\hline & & $\begin{array}{l}\text { II (Stratum 1: } \\
\text { monotherapy } \\
\text { Stratum 2: + LAR } \\
\text { octreotide (in those } \\
\text { who had received } \\
\text { octreotide previously) }\end{array}$ & $\begin{array}{l}\text { Pancreatic NET } \\
(\mathrm{n}=160 ; \text { stratum } 1=115 ; \\
\text { stratum } 2=45)\end{array}$ & $\begin{array}{l}\text { Pancreatic NET: Stratum 1: } 9.6 \% \text { PR; } \\
67.8 \% \text { SD; } 13.9 \%=\text { PD; median PFS = } \\
9.7 \text { months } \\
\text { Stratum } 2: 4.4 \% \text { PR; } 80 \% \text { SD; } 0 \%=\text { PD; } \\
\text { median PFS = } 16.7 \text { months }\end{array}$ & $\begin{array}{l}\text { Yao et al. [103], } \\
2010\end{array}$ \\
\hline & & III & $\begin{array}{l}\text { Pancreatic NET } \\
\text { (410; } 207 \text { received everolimus) }\end{array}$ & $\begin{array}{l}\text { Pancreatic NET: median PFS } 11.0 \text { vs. } \\
4.6 \text { months with placebo } \\
\text { Estimate for proportion PF at } \\
18 \text { months }=34 \%\end{array}$ & $\begin{array}{l}\text { Yao et al. [104], } \\
2011\end{array}$ \\
\hline Temsirolimus & mTOR & II & $\begin{array}{l}\text { Pancreatic or gastrointestinal NET } \\
\text { (37; one did not receive treatment; } \\
13 \text { with pancreatic NET) }\end{array}$ & $\begin{array}{l}\text { Study population: } 5.6 \% \text { PR; } \\
\text { median TTP = } 6 \text { months; } \\
\text { 1-year OS rate }=71.5 \% \\
\text { Pancreatic NET: } 6.7 \% \text { PR; } 60 \% \text { SD; } \\
\text { 26.7\% PD; median TTP } 6 \text { months = } \\
51.6 \% \text {; } 1 \text {-year OS rate } 71.5 \%\end{array}$ & $\begin{array}{l}\text { Duran et al. [105], } \\
2006\end{array}$ \\
\hline
\end{tabular}

${ }^{a}$ As specified in each publication. ${ }^{\mathrm{b}}$ Most advanced phase (all prospective studies). CSF-1R $=$ Colony-stimulating factor 1 receptor; RET $=$ glial cell linederived neurotrophic factor receptor (rearranged during transfection); FLT3 = FMS-like tyrosine kinase-3; PD = progressive disease; $\mathrm{PF}=$ progression-free; $\mathrm{NR}=$ not reached; $\mathrm{CR}=$ complete response; $\mathrm{MR}=$ minimal response. 
Somatostatin Analogs and Peptide Receptor

Radiotherapy

Somatostatin Analogs

Currently available somatostatin analogs comprise octreotide and lanreotide, available as depot formulations; octreotide is also available as an immediate-release formulation. The question of whether somatostatin analogs - predominantly used for symptom relief - have any antitumor activity has been hotly debated. Prospective and retrospective clinical studies have revealed that the use of somatostatin analogs is associated with tumor growth stabilization in $50-60 \%$ of gastroenteropancreatic NET patients, whereas partial tumor remissions rarely occur $[69,70]$. However, there are limited data in pancreatic NET exclusively. In a prospective study of 21 patients with pancreatic NET treated with octreotide long-acting release (LAR), 38\% had stable disease (SD) after a median follow-up of 49.5 months. While one prospective placebocontrolled study confirmed an antitumor effect in midgut NET, the applicability of the data to pancreatic NET remains unclear [71-73]. Recent data have shed light on the biological effect of octreotide, with the demonstration that SSTR2 (located in the cell membrane in untreated patients) becomes internalized following high-dose octreotide therapy in patients with NET [74].

Potential advances in this area include the development of somatostatin/dopamine chimeric compounds [68]; the pan-somatostatin analog pasireotide, which has affinity for SSTR1, SSTR2, SSTR3, and SSTR5 [75, 76]; and also non-peptidic somatostatin analogs with high affinity and selectivity for SSTR1 [77-79] and SSTR3 [80]. These compounds have yet to be tested for efficacy.

Peptide Receptor Radiotherapy

The presence of SSTRs on gastrointestinal and pancreatic NETs has been exploited to achieve targeted delivery of radiotherapy, using radiolabeled somatostatin analogs (indium-111, yttrium-90, or lutetium-177). Results from phase II trials of patients with various types of NET have shown that radionuclide treatment using ${ }^{90} \mathrm{Y}$-DOTATOC ([90 Y-DOTA]-D-Phe ${ }^{1}-\mathrm{Tyr}^{3}$-octreotide) produces partial responses (PR) in $4-35 \%$ of patients $[81,82]$. Recently, Cwikla et al. [83] found ${ }^{90}$ Y-DOTATATE ([90Y-DOTA ${ }^{0}$, $\mathrm{D}$-Phe $\left.{ }^{1}-\mathrm{Tyr}^{3}\right]$-octreotate) to be effective in patients $(\mathrm{n}=$ 60) with gastroenteropancreatic NET; $23 \%$ had PR and the remaining $77 \%$ of patients had SD. Response rates with ${ }^{177} \mathrm{Lu}$-DOTATATE ([$\left.{ }^{177} \mathrm{Lu}-\mathrm{DOTA}^{0}, \mathrm{Tyr}^{3}\right]$-octreotate) are also encouraging in patients with several types of pancreatic and other gastrointestinal NET, with an objective response rate (ORR) of approximately 43\% (com- plete response $4.4 \%$ and PR 38.5\%) in the pancreatic NET group [84]. To date, prospective studies comparing 'hot' with 'cold' somatostatin analogs with respect to their symptom-controlling as well as their antiproliferative efficacy are lacking.

\section{RTK Inhibitors and Antiangiogenic Agents}

\section{Sunitinib}

Sunitinib is an oral, multitargeted RTK inhibitor of VEGFR-1-3, PDGFR, c-kit, RET, CSF-1R, and FLT3, with direct antitumor and antiangiogenic effects. In the RIP1Tag2 transgenic mouse model of pancreatic NET, sunitinib reduced tumor burden and increased survival, reduced the endothelial cell population, and reduced pericyte coverage $[29,53]$. In a phase II clinical trial in patients with advanced carcinoid $(n=41)$ or pancreatic NET $(n=66)$, the overall ORR was $16.7 \%$ in patients with pancreatic NET, and a further $68 \%$ had SD [85]. Median time to tumor progression (TTP) was 7.7 months and 1-year survival was $81.1 \%$ in patients with pancreatic NET. A phase III, randomized, double-blind trial of sunitinib versus placebo in patients with progressive, well-differentiated, malignant pancreatic NET was closed early because of the greater risk of progression and death in patients assigned to placebo [86]. Median progression-free survival (PFS) with sunitinib was 11.4 months and with placebo was 5.5 months (hazard ratio 0.42 ; $95 \%$ CI $0.26-0.66$; $\mathrm{p}<0.001$ ). Based on these positive results, the European Commission approved sunitinib (SUTENT ${ }^{\circledR}$, Pfizer Inc.) for the treatment of unresectable or metastatic, well-differentiated pancreatic NET with disease progression in December 2010.

\section{Sorafenib}

Sorafenib is an orally active, multikinase inhibitor with selectivity for the RTKs VEGFR-2, VEGFR-3, PDGFR- $\beta$, FLT3, c-kit, and RET, as well as for the serine/ threonine RAF kinases, B-Raf and Raf-1/C-Raf, which are associated with activation of these RTKs. To date, results have been reported from a single phase II study of sorafenib, which included two cohorts of patients with, respectively, gastrointestinal tumors $(n=50)$ and pancreatic NET $(n=43)$ [87]. In patients with pancreatic NET, the ORR was $10 \%$, and 14 of 23 evaluable patients (61\%) were progression-free at 6 months.

\section{Vatalanib}

Vatalanib inhibits all known VEGFRs, with particular selectivity for VEGFR-2; at higher concentrations vatalanib also inhibits PDGFR- $\beta$ and c-kit. One phase II trial is ongoing in patients with progressive, advanced 
NET (NCT00590343); however, no specific data on pancreatic NET have been published [88]. In another study, 4 of 20 patients enrolled had pancreatic NET; overall, the best response was SD (8/16 patients at 6 months) in heavily pretreated patients, with a median TTP of 7 months [89].

\section{Imatinib}

Imatinib is an orally available phenylaminopyrimidine analog which specifically inhibits tyrosine kinase activity associated with c-kit, PDGFR- $\alpha$, PDGFR- $\beta$, and BCR-ABL. Imatinib inhibited cell proliferation and induced apoptosis in both c-kit-positive and c-kit-negative neuroendocrine cells in vitro [42]. Although imatinib has been investigated in some types of NET [90, 91], few patients with pancreatic NET have been enrolled and there is currently no evidence of clinical activity in this tumor type.

\section{Gefitinib}

Gefitinib is an EGFR-specific tyrosine kinase inhibitor. Blockade of EGFR using gefitinib inhibited growth of pancreatic NET cell lines in vitro, inducing apoptosis and cell cycle arrest [92].

The activity of gefitinib has been assessed in a phase II study of patients with advanced NET [93]. PFS at 6 months was $31 \%$ for 29 evaluable patients with pancreatic NET; 2 of these patients achieved a PR and 4 patients had SD exceeding 4 months.

\section{Bevacizumab}

Bevacizumab is a monoclonal antibody that binds to, and neutralizes, all biologically active forms of VEGF. In preclinical experiments, bevacizumab failed to inhibit growth of BON pancreatic NET cells in vitro, but reduced their angiogenic potential by blocking the cells' ability to stimulate endothelial cell tube formation and proliferation [94]. Treatment with bevacizumab impaired tumor growth in a xenograft model using BON cells.

In a phase II study of bevacizumab plus temozolomide in patients with advanced NET [95], 18 of 34 patients enrolled had pancreatic NET, of whom four (24\%) achieved a PR and a further 12 (70\%) exhibited SD. Two ongoing phase II trials are open to patients with advanced NET, including those of pancreatic origin [96, 97]. In a study of bevacizumab combined with the oxaliplatin-based chemotherapy regimen, FOLFOX (oxaliplatin, leucovorin, and 5-fluorouracil), 2 of 6 patients with pancreatic NET enrolled achieved a PR and 4 had SD
[98]. Since comparative trials of chemotherapy versus chemotherapy plus bevacizumab are lacking, and chemotherapeutic drugs alone may induce high remission rates in pancreatic NET (as has recently been shown by the use of capecitabine and temozolomide [99]), it remains an open question whether the addition of bevacizumab to systemic chemotherapy increases response rate or PFS.

\section{Inhibitors of Intracellular and Downstream Targets \\ Everolimus}

Everolimus is an orally available derivative of rapamycin, which inhibits the activity of mTOR. Preclinical studies have shown the antiproliferative effects of everolimus in human pancreatic endocrine cells in vitro and in vivo $[100,101]$. Application of everolimus was also associated with attenuated phosphorylation of all downstream targets of Akt, including TSC2, mTOR, and p70S6K [100], and with G0-/G1-phase arrest, as well as induction of apoptosis [101].

The combination of everolimus plus octreotide was investigated in a phase II study in advanced, low-to-intermediate grade NET [102]. Among 30 enrolled patients with pancreatic NET, 8 patients obtained a PR (27\%) and 18 had SD (60\%). Median PFS in this group was 50 weeks; median OS had not been reached. Another phase II study of everolimus in metastatic pancreatic NET after failure of chemotherapy has recently been published [103]. Patients with progressive disease who were not being treated with octreotide at study entry received single-agent everolimus (stratum $1 ; \mathrm{n}=115$ ), while patients who had been on octreotide LAR for at least 3 months, but also had evidence of progression, received everolimus plus octreotide (stratum $2 ; \mathrm{n}=45$ ). In stratum $1,9.6 \%$ of patients achieved a PR and $67.8 \%$ had SD; in stratum 2, 4.4 and $80 \%$ of patients had a PR or SD, respectively, as their best response. Median PFS was 9.7 months and 16.7 months in strata 1 and 2, respectively. A phase III, randomized, double-blind trial of everolimus plus best supportive care versus placebo plus best supportive care in patients with progressive, well-differentiated, malignant pancreatic NET confirmed the activity of everolimus. Median PFS with everolimus was 11 months and with placebo was 4.6 months (hazard ratio $=0.35$ [95\% CI $0.27-0.45]$; $\mathrm{p}<$ 0.0001 ) [104]. Estimates of the proportion of patients alive and progression-free at 18 months were 34\% (95\% CI 2643) with everolimus, compared with $9 \%$ (95\% CI 4-16) with placebo. Based on the results of this phase III study, regulatory submission for everolimus to treat patients with NET is underway. 
Table 4. Summary of targeted agents in phase I or early phase II clinical development with potential for use in pancreatic neuroendocrine tumors

\begin{tabular}{|c|c|c|c|c|}
\hline Agent & Target & Phase & Population & Reference/NCT identifier \\
\hline Pasireotide & $\begin{array}{l}\text { SSTR1, SSTR2, } \\
\text { SSTR3 and SSTR5 }\end{array}$ & Phase II, monotherapy & Metastatic NET & NCT01253161 \\
\hline${ }^{90} \mathrm{Y}$-DOTATOC & SSTR & Phase I & $\begin{array}{l}\text { Malignancies expressing } \\
\text { somatostatin receptors }\end{array}$ & NCT00006368 \\
\hline${ }^{177} \mathrm{Lu}-\mathrm{DOTATOC}$ & SSTR & Phase II & Mixed NET & NCT00978211 \\
\hline \multirow[t]{2}{*}{ AMG 479} & \multirow[t]{2}{*}{ IGF-1R } & Phase I & Solid malignancies/NHL & Tolcher [126], 2009 \\
\hline & & Phase II & Gastrointestinal or pancreatic NET & NCT01024387 \\
\hline $\begin{array}{l}\text { MK-0646 } \\
\text { (dalotuzumab) }\end{array}$ & IGF-1R & Phase I & Solid malignancies & Atzori [127], 2008; Hidalgo [128], 2008; \\
\hline \multirow[t]{2}{*}{ MK-2206 } & \multirow{2}{*}{$\begin{array}{l}\text { Allosteric Akt } \\
\text { inhibitor }\end{array}$} & Phase I & Solid tumors & Tolcher et al. [131], 2009 \\
\hline & & Phase II & Gastrointestinal or pancreatic NET & NCT01169649 \\
\hline \multirow{3}{*}{$\begin{array}{l}\text { Romidepsin } \\
\text { (FR901288/ } \\
\text { depsipeptide) }\end{array}$} & \multirow[t]{3}{*}{ Histone deacetylase } & Phase I & Thyroid and other advanced cancers & Piekarz [132], 2008 \\
\hline & & Phase I/II & Solid malignancies & NCT00379639 \\
\hline & & Phase II & Gastrointestinal or pancreatic NET & NCT00084461 \\
\hline \multirow[t]{2}{*}{ AZD0530 } & \multirow[t]{2}{*}{ scr/abl } & Phase I, monotherapy & Solid malignancies & NCT00704366 \\
\hline & & $\begin{array}{l}\text { Phase I, in combination } \\
\text { with cediranib (AZD2171) }\end{array}$ & Solid malignancies & Trarbach [133], 2008 \\
\hline
\end{tabular}

RCC $=$ Renal cell carcinoma.

Temsirolimus

Like everolimus, temsirolimus is a rapamycin derivative with specific activity against mTOR. To date, a single phase II trial of temsirolimus in advanced NET has been published [105]. Among 15 patients with advanced pancreatic NET and 21 patients with gastrointestinal tumors enrolled, 1 patient with each tumor type achieved a PR (ORR, 6.7 and 4.8\%, respectively). The overall median TTP was 6.0 months, and one-year PFS was $40.1 \%$. Median OS had not been reached.

\section{Dual Therapeutic Targeting}

Combined targeting of mTOR and EGFR signaling pathways has shown potential clinical benefit in the RIP1Tag2 model, compared with inhibition of either pathway in monotherapy [106]. A phase II trial is ongoing to evaluate the efficacy of this treatment regimen in human NET (NCT00843531).

\section{Agents in Early Clinical Development}

A number of agents directed at molecular targets that appear relevant in the pathology of pancreatic NET (as discussed above) are currently in phase I or early phase II clinical development (table 4); these include, in particular, agents directed at SSTRs and insulin-like growth factor type 1 receptor (IGF-1R), as well as an inhibitor of histone deacetylase.

In summary, pancreatic NET are a diverse group of tumors which vary in their degree of malignancy and functionality. Before the development of targeted agents, several systemic options were available to control tumor growth and improve patients' quality of life, including interferon therapy, somatostatin analogs and cytotoxic chemotherapy. While chemotherapy may induce significant tumor shrinkage, these effects are transient. Researchers have therefore investigated molecular targets that offer scope for new therapeutic approaches that could significantly improve management of patients with pancreatic NET. We have undertaken an extensive review 
of published literature on targets specific to pancreatic NET, and have summarized the available clinical data for agents directed at some of these targets.

Preclinical experiments have demonstrated the relevance of angiogenesis in the development of pancreatic NET. Several RTKs with both angiogenic and direct roles in supporting tumor growth are expressed to varying degrees in human pancreatic NET biopsies, although interpretation of the published literature is complicated by differences in technique. In the clinic, preliminary activity in pancreatic NET has been reported with several RTK inhibitors. Most notably, the multitargeted RTK inhibitor, sunitinib, has recently demonstrated superiority over placebo in a randomized phase III study and has received approval by the European Commission for treating patients with pancreatic NET.

The PI3K/Akt/mTOR pathway, with its critical role in regulating cell growth and apoptosis, is also implicated in the growth of pancreatic NET. The mTOR inhibitor, everolimus, has demonstrated activity after failure of chemotherapy in a large phase II trial and superiority over placebo in a placebo-controlled phase III trial. Everolimus and sunitinib are the two most advanced of all molecular targeted drugs in the field of NET and can be considered similarly effective in pancreatic NET with respect to PFS.

In conclusion, several targeted agents have potentially useful activity in pancreatic NET. More randomized, carefully designed studies are urgently needed to assess the real benefits of these agents, either alone or in combination. The rarity of pancreatic NET means that enrollment is likely to be slow, and cooperative, multicenter studies will be needed to progress development in a timely fashion.

\section{Acknowledgments}

Medical writing support was provided by Andy Gannon and Jean Scott of ACUMED ${ }^{\circledR}$ (Tytherington, UK) with funding from Pfizer Inc.

\section{Disclosure Statement}

Financial Support: Medical writing support was provided by Andy Gannon of ACUMED ${ }^{\circledR}$ (Tytherington, UK) and was funded by Pfizer Inc.

\section{References}

1 Yao JC, Hassan M, Phan A, et al: One hundred years after 'carcinoid': epidemiology of and prognostic factors for neuroendocrine tumors in 35,825 cases in the United States. J Clin Oncol 2008;26:3063-3072.

2 Zhou J, Enewold L, Stojadinovic A, et al: Incidence rates of exocrine and endocrine pancreatic cancers in the United States. Cancer Causes Control 2010;21:853-861.

3 Modlin IM, Oberg K, Chung DC, et al: Gastroenteropancreatic neuroendocrine tumours. Lancet Oncol 2008;9:61-72.

4 Metz DC, Jensen RT: Gastrointestinal neuroendocrine tumors: pancreatic endocrine tumors. Gastroenterology 2008; 135:14691492.

5 Kumar U, Grant M: Somatostatin and somatostatin receptors. Results Probl Cell Differ 2010;50:137-184.

6 Patel YC: Molecular pharmacology of somatostatin receptor subtypes. J Endocrino Invest 1997;20:348-367.

7 Lamberts SW, van der Lely AJ, de Herder WW, Hofland LJ: Octreotide. N Engl J Med 1996:334:246-254.

8 Susini C, Buscail L: Rationale for the use of somatostatin analogs as antitumor agents. Ann Oncol 2006;17:1733-1742.
9 Grozinsky-Glasberg S, Shimon I, Korbonits M, Grossman AB: Somatostatin analogues in the control of neuroendocrine tumours: efficacy and mechanisms. Endocr Relat Cancer 2008;15:701-720.

10 Schonbrunn A: Somatostatin receptors present knowledge and future directions. Ann Oncol 1999;10(suppl 2):S17-S21.

-11 Kulaksiz H, Eissele R, Rossler D, et al: Identification of somatostatin receptor subtypes $1,2 \mathrm{~A}, 3$, and 5 in neuroendocrine tumours with subtype specific antibodies. Gut 2002; 50:52-60

12 Papotti M, Bongiovanni M, Volante M, et al: Expression of somatostatin receptor types 1-5 in 81 cases of gastrointestinal and pancreatic endocrine tumors. A correlative immunohistochemical and reverse-transcriptase polymerase chain reaction analysis. Virchows Arch 2002;440:461-475.

13 Fjallskog ML, Ludvigsen E, Stridsberg M, Oberg K, Eriksson B, Janson ET: Expression of somatostatin receptor subtypes 1 to 5 in tumor tissue and intratumoral vessels in malignant endocrine pancreatic tumors. Med Oncol 2003;20:59-67.
14 Portela-Gomes GM, Stridsberg M, Grimelius L, Rorstad O, Janson ET: Differential expression of the five somatostatin receptor subtypes in human benign and malignant insulinomas - predominance of receptor subtype 4. Endocr Pathol 2007;18:79-85.

15 Fazio N, Cinieri S, Lorizzo K, et al: Biological targeted therapies in patients with advanced enteropancreatic neuroendocrine carcinomas. Cancer Treat Rev 2010;36(suppl 3):S87S94.

16 Eriksson B: New drugs in neuroendocrine tumors: rising of new therapeutic philosophies? Curr Opin Oncol 2010;22:381-386.

17 Tang C, Biemond I, Lamers CB: Expression of peptide receptors in human endocrine tumours of the pancreas. Gut 1997;40:267-271.

18 Reubi JC, Waser B: Concomitant expression of several peptide receptors in neuroendocrine tumours: molecular basis for in vivo multireceptor tumour targeting. Eur J Nucl Med Mol Imaging 2003;30:781-793.

19 Reubi JC, Waser B, Gugger M, et al: Distribution of CCK1 and CCK2 receptors in normal and diseased human pancreatic tissue. Gastroenterology 2003;125:98-106.

20 Reubi JC, Macke HR, Krenning EP: Candidates for peptide receptor radiotherapy today and in the future. J Nucl Med 2005; 46(suppl 1):67S-75S. 
21 Nakayama S, Yokote T, Kobayashi K, et al: VIPoma with expression of both VIP and VPAC1 receptors in a patient with WDHA syndrome. Endocrine 2009;35:143-146.

22 Hanahan D: Heritable formation of pancreatic beta-cell tumours in transgenic mice expressing recombinant insulin/simian virus 40 oncogenes. Nature 1985;315:115-122.

-23 Folkman J, Watson K, Ingber D, Hanahan D: Induction of angiogenesis during the transition from hyperplasia to neoplasia. Nature 1989;339:58-61.

24 Christofori G, Naik P, Hanahan D: Vascular endothelial growth factor and its receptors, flt- 1 and flk-1, are expressed in normal pancreatic islets and throughout islet cell tumorigenesis. Mol Endocrinol 1995;9:1760-1770.

-25 Inoue M, Hager JH, Ferrara N, Gerber HP, Hanahan D: VEGF-A has a critical, nonredundant role in angiogenic switching and pancreatic beta cell carcinogenesis. Cancer Cell 2002;1:193-202.

-26 Parangi S, O'Reilly M, Christofori G, et al: Antiangiogenic therapy of transgenic mice impairs de novo tumor growth. Proc Natl Acad Sci USA 1996;93:2002-2007.

-27 Bergers G, Javaherian K, Lo KM, Folkman J, Hanahan D: Effects of angiogenesis inhibitors on multistage carcinogenesis in mice. Science 1999;284:808-812.

-28 Casanovas O, Hicklin DJ, Bergers G, Hanahan D: Drug resistance by evasion of antiangiogenic targeting of VEGF signaling in latestage pancreatic islet tumors. Cancer Cell 2005;8:299-309.

29 Pietras K, Hanahan D: A multitargeted, metronomic, and maximum-tolerated dose 'chemo-switch' regimen is antiangiogenic, producing objective responses and survival benefit in a mouse model of cancer. J Clin Oncol 2005;23:939-952.

- 30 Mancuso MR, Davis R, Norberg SM, et al: Rapid vascular regrowth in tumors after reversal of VEGF inhibition. J Clin Invest 2006;116:2610-2621.

- 31 Marion-Audibert AM, Barel C, Gouysse G, et al: Low microvessel density is an unfavorable histoprognostic factor in pancreatic endocrine tumors. Gastroenterology 2003;125: 1094-1104.

- 32 Couvelard A, O’Toole D, Turley H, et al: Microvascular density and hypoxia-inducible factor pathway in pancreatic endocrine tumours: negative correlation of microvascular density and VEGF expression with tumour progression. Br J Cancer 2005;92:94-101.

-33 Hansel DE, Rahman A, Hermans J, et al: Liver metastases arising from well-differentiated pancreatic endocrine neoplasms demonstrate increased VEGF-C expression. Mod Pathol 2003;16:652-659.

34 Rubbia-Brandt L, Terris B, Giostra E, Dousset B, Morel P, Pepper MS: Lymphatic vessel density and vascular endothelial growth factor- $\mathrm{C}$ expression correlate with malignant behavior in human pancreatic endocrine tumors. Clin Cancer Res 2004;10:6919-6928.
5 Detjen KM, Rieke S, Deters A, et al: Angiopoietin-2 promotes disease progression of neuroendocrine tumors. Clin Cancer Res 2010;16:420-429.

36 Figueroa-Vega N, Diaz A, Adrados M, et al: The association of the angiopoietin/Tie-2 system with the development of metastasis and leukocyte migration in neuroendocrine tumors. Endocr Relat Cancer 2010;17:897908.

37 Srirajaskanthan R, Dancey G, Hackshaw A, Luong T, Caplin ME, Meyer T: Circulating angiopoietin-2 is elevated in patients with neuroendocrine tumours and correlates with disease burden and prognosis. Endocr Relat Cancer 2009;16:967-976.

38 Fjallskog ML, Lejonklou MH, Oberg KE, Eriksson BK, Janson ET: Expression of molecular targets for tyrosine kinase receptor antagonists in malignant endocrine pancreatic tumors. Clin Cancer Res 2003;9:14691473.

- 39 Fjallskog ML, Hessman O, Eriksson B, Janson ET: Upregulated expression of PDGF receptor beta in endocrine pancreatic tumors and metastases compared to normal endocrine pancreas. Acta Oncol 2007;46:741-746.

40 Couvelard A, Hu J, Steers G, et al: Identification of potential therapeutic targets by geneexpression profiling in pancreatic endocrine tumors. Gastroenterology 2006;131:15971610.

41 Kostoula V, Khan K, Savage K, et al: Expression of c-kit (CD117) in neuroendocrine tumours - a target for therapy? Oncol Rep 2005; 13:643-647.

42 Lankat-Buttgereit B, Horsch D, Barth P, Arnold R, Blocker S, Goke R: Effects of the tyrosine kinase inhibitor imatinib on neuroendocrine tumor cell growth. Digestion 2005; 71:131-140.

43 Ferrari L, Della TS, Collini P, et al: Kit protein (CD117) and proliferation index (Ki-67) evaluation in well and poorly differentiated neuroendocrine tumors. Tumori 2006;92: 531-535.

44 Zhang L, Smyrk TC, Oliveira AM, et al: KIT is an independent prognostic marker for pancreatic endocrine tumors: a finding derived from analysis of islet cell differentiation markers. Am J Surg Pathol 2009;33: 1562-1569.

45 Wulbrand U, Wied M, Zofel P, Goke B, Arnold R, Fehmann H: Growth factor receptor expression in human gastroenteropancreatic neuroendocrine tumours. Eur J Clin Invest 1998;28:1038-1049.

46 Srivastava A, Alexander J, Lomakin I, Dayal Y: Immunohistochemical expression of transforming growth factor alpha and epidermal growth factor receptor in pancreatic endocrine tumors. Hum Pathol 2001;32: 1184-1189.

47 Peghini PL, Iwamoto M, Raffeld M, et al: Overexpression of epidermal growth factor and hepatocyte growth factor receptors in a proportion of gastrinomas correlates with aggressive growth and lower curability. Clin Cancer Res 2002;8:2273-2285.

48 Papouchado B, Erickson LA, Rohlinger AL, et al: Epidermal growth factor receptor and activated epidermal growth factor receptor expression in gastrointestinal carcinoids and pancreatic endocrine carcinomas. Mod Pathol 2005; 18:1329-1335.

49 Bergmann F, Breinig M, Hopfner M, et al: Expression pattern and functional relevance of epidermal growth factor receptor and cyclooxygenase-2: novel chemotherapeutic targets in pancreatic endocrine tumors? Am J Gastroenterol 2009;104:171-181.

50 Srirajaskanthan R, Shah T, Watkins J, Marelli L, Khan K, Caplin ME: Expression of the HER-1-4 family of receptor tyrosine kinases in neuroendocrine tumours. Oncol Rep 2010;23:909-915.

51 Di Florio A, Capurso G, Milione M, et al: Src family kinase activity regulates adhesion, spreading and migration of pancreatic endocrine tumour cells. Endocr Relat Cancer 2007;14:111-124.

52 Capurso G, Lattimore S, Crnogorac-Jurcevic $\mathrm{T}$, et al: Gene expression profiles of progressive pancreatic endocrine tumours and their liver metastases reveal potential novel markers and therapeutic targets. Endocr Relat Cancer 2006;13:541-558.

53 Yao VJ, Sennino B, Davis RB, et al: Combined anti-VEGFR and anti-PDGFR actions of sunitinib on blood vessels in preclinical tumor models. 18th EORTC-NCI-AACR Symposium on Molecular Targets and Cancer Therapeutics, Prague, 2006.

54 Perren A, Komminoth P, Saremaslani P, et al: Mutation and expression analyses reveal differential subcellular compartmentalization of PTEN in endocrine pancreatic tumors compared to normal islet cells. Am J Pathol 2000;157:1097-1103.

55 Wang L, Ignat A, Axiotis CA: Differential expression of the PTEN tumor suppressor protein in fetal and adult neuroendocrine tissues and tumors: progressive loss of PTEN expression in poorly differentiated neuroendocrine neoplasms. Appl Immunohistochem Mol Morphol 2002;10:139-146.

56 Dworakowska D, Grossman AB: Are neuroendocrine tumours a feature of tuberous sclerosis? A systematic review. Endocr Relat Cancer 2009; 16:45-58.

57 Francalanci P, Omedi-Camassei F, Purificato $\mathrm{C}$, et al: Malignant pancreatic endocrine tumor in a child with tuberous sclerosis. Am J Surg Pathol 2003;27:1386-1389.

58 Merritt JL, Davis DM, Pittelkow MR, Babovic-Vuksanovic D: Extensive acrochordons and pancreatic islet-cell tumors in tuberous sclerosis associated with TSC2 mutations. Am J Med Genet A 2006;140:1669-1672.

-59 Johannessen CM, Reczek EE, James MF, Brems H, Legius E, Cichowski K: The NF1 tumor suppressor critically regulates TSC2 and mTOR. Proc Natl Acad Sci USA 2005; 102:8573-8578. 
60 Perren A, Wiesli P, Schmid S, et al: Pancreatic endocrine tumors are a rare manifestation of the neurofibromatosis type 1 phenotype: molecular analysis of a malignant insulinoma in a NF-1 patient. Am J Surg Pathol 2006;30:1047-1051.

-61 Missiaglia E, Dalai I, Barbi S, et al: Pancreatic endocrine tumors: expression profiling evidences a role for AKT-mTOR pathway. J Clin Oncol 2010;28:245-255.

-62 Ishibashi M, Fujisawa M, Furue H, Maeda Y, Fukayama M, Yamaji T: Inhibition of growth of human small cell lung cancer by bromocriptine. Cancer Res 1994;54:3442-3446.

63 Pathak RD, Tran TH, Burshell AL: A case of dopamine agonists inhibiting pancreatic polypeptide secretion from an islet cell tumor. J Clin Endocrinol Metab 2004;89:581584.

-64 Lemmer K, Ahnert-Hilger G, Hopfner M, et al: Expression of dopamine receptors and transporter in neuroendocrine gastrointestinal tumor cells. Life Sci 2002;71:667-678.

-65 Grossrubatscher E, Veronese S, Ciaramella PD, et al: High expression of dopamine receptor subtype 2 in a large series of neuroendocrine tumors. Cancer Biol Ther 2008;7: 1970-1978.

-66 Pivonello R, Ferone D, de Herder WW, et al: Dopamine receptor expression and function in corticotroph ectopic tumors. J Clin Endocrinol Metab 2007;92:65-69.

-67 Srirajaskanthan R, Watkins J, Marelli L, Khan K, Caplin ME: Expression of somatostatin and dopamine 2 receptors in neuroendocrine tumours and the potential role for new biotherapies. Neuroendocrinology 2009;89:308-314.

-68 Kidd M, Drozdov I, Joseph R, Pfragner R, Culler M, Modlin I: Differential cytotoxicity of novel somatostatin and dopamine chimeric compounds on bronchopulmonary and small intestinal neuroendocrine tumor cell lines. Cancer 2008;113:690-700.

69 Butturini G, Bettini R, Missiaglia E, et al: Predictive factors of efficacy of the somatostatin analogue octreotide as first line therapy for advanced pancreatic endocrine carcinoma. Endocr Relat Cancer 2006;13:1213-1221.

-70 Modlin IM, Pavel M, Kidd M, Gustafsson BI: Review article: somatostatin analogues in the treatment of gastroenteropancreatic neuroendocrine (carcinoid) tumours. Aliment Pharmacol Ther 2010;31:169-188.

71 Plockinger U, Wiedenmann B: Neuroendocrine tumors: biotherapy. Best Pract Res Clin Endocrinol Metab 2007;21:145-162.

-72 Rinke A, Muller HH, Schade-Brittinger C, et al: Placebo-controlled, double-blind, prospective, randomized study on the effect of octreotide LAR in the control of tumor growth in patients with metastatic neuroendocrine midgut tumors: a report from the PROMID Study Group. J Clin Oncol 2009; 27:4656-4663.
73 Oberg KE: Is it time to widen the use of somatostatin analogs in neuroendocrine tumors? J Clin Oncol 2009;27:4635-4636.

74 Reubi JC, Waser B, Cescato R, Gloor B, Stettler C, Christ E: Internalized somatostatin receptor subtype 2 in neuroendocrine tumors of octreotide-treated patients. J Clin Endocrinol Metab 2010;95:2343-2350.

75 Bruns C, Lewis I, Briner U, Meno-Tetang G, Weckbecker G: SOM230: a novel somatostatin peptidomimetic with broad somatotropin release inhibiting factor (SRIF) receptor binding and a unique antisecretory profile. Eur J Endocrinol 2002;146:707-716.

76 Ben-Shlomo A, Melmed S: Pasireotide - a somatostatin analog for the potential treatment of acromegaly, neuroendocrine tumors and Cushing's disease. IDrugs 2007;10:885-895.

-77 Troxler T, Hoyer D, Langenegger D, et al: Identification and SAR of potent and selective non-peptide obeline somatostatin SST1 receptor antagonists. Bioorg Med Chem Lett 2007;17:3983-3987.

78 Troxler T, Enz A, Hoyer D, et al: Ergoline derivatives as highly potent and selective antagonists at the somatostatin SST 1 receptor. Bioorg Med Chem Lett 2008;18:979-982.

79 Troxler T, Hurth K, Mattes H, et al: Discovery of novel non-peptidic beta-alanine piperazine amide derivatives and their optimization to achiral, easily accessible, potent and selective somatostatin SST1 receptor antagonists. Bioorg Med Chem Lett 2009;19:1305-1309.

80 Troxler T, Hurth K, Schuh KH, et al: Decahydroisoquinoline derivatives as novel nonpeptidic, potent and subtype-selective somatostatin SST(3) receptor antagonists. Bioorg Med Chem Lett 2010;20:1728-1734.

81 Waldherr C, Pless M, Maecke HR, Haldemann A, Mueller-Brand J: The clinical value of [90Y-DOTA]-D-Phe1-Tyr3-octreotide (90Y-DOTATOC) in the treatment of neuroendocrine tumours: a clinical phase II study. Ann Oncol 2001;12:941-945.

82 Paganelli G, Zoboli S, Cremonesi M, et al: Receptor-mediated radiotherapy with 90YDOTA-D-Phe1-Tyr3-octreotide. Eur J Nucl Med 2001;28:426-434.

83 Cwikla JB, Sankowski A, Seklecka N, et al: Efficacy of radionuclide treatment DOTATATE Y-90 in patients with progressive metastatic gastroenteropancreatic neuroendocrine carcinomas (GEP-NETs): a phase II study. Ann Oncol 2010;21:787-794.

84 Kwekkeboom DJ, de Herder WW, Kam $\mathrm{BL}$, et al: Treatment with the radiolabeled somatostatin analog [177 Lu-DOTA 0, Tyr3] octreotate: toxicity, efficacy, and survival. J Clin Oncol 2008;26:2124-2130.

85 Kulke MH, Lenz HJ, Meropol NJ, et al: Activity of sunitinib in patients with advanced neuroendocrine tumors. J Clin Oncol 2008; 26:3403-3410.

86 Raymond E, Dahan L, Raoul JL, et al: Sunitinib malate for the treatment of pancreatic neuroendocrine tumors. N Engl J Med 2011; 364:501-513.
87 Hobday TJ, Rubin J, Holen K, et al: MC044h, a phase II trial of sorafenib in patients (pts) with metastatic neuroendocrine tumors (NET): a Phase II Consortium (P2C) study. J Clin Oncol 2007;25:abstr.

88 Anthony L, Chester M, Michael S, O’Dorisio TM, O'Dorisio MS: Phase II open-label clinical trial of vatalanib (PTK/ZK) in patients with progressive neuroendocrine cancer. J Clin Oncol 2008;26:abstr.

89 Pavel ME, Bartel C, Heuck F, et al: Open-label, non-randomized, multicenter phase II study evaluating the angiogenesis inhibitor PTK787/ ZK222584 (PTK/ZK) in patients with advanced neuroendocrine carcinomas (NEC). J Clin Oncol 2008;26:abstr.

90 Gross DJ, Munter G, Bitan M, et al: The role of imatinib mesylate (Glivec) for treatment of patients with malignant endocrine tumors positive for c-kit or PDGF-R. Endocr Relat Cancer 2006;13:535-540.

91 Yao JC, Zhang JX, Rashid A, et al: Clinical and in vitro studies of imatinib in advanced carcinoid tumors. Clin Cancer Res 2007;13: 234-240.

92 Höpfner M, Sutter AP, Gerst B, Zeitz M, Scherubl H: A novel approach in the treatment of neuroendocrine gastrointestinal tumours: targeting the epidermal growth factor receptor by gefitinib (ZD1839). Br J Cancer 2003;89:1766-1775.

93 Hobday TJ, Holen K, Donehower R, et al: A phase II trial of gefitinib in patients (pts) with progressive metastatic neuroendocrine tumors (NET): A Phase II Consortium (P2C) study. J Clin Oncol 2006;24:abstr.

94 Zhang J, Jia Z, Li Q, et al: Elevated expression of vascular endothelial growth factor correlates with increased angiogenesis and decreased progression-free survival among patients with low-grade neuroendocrine tumors. Cancer 2007;109:1478-1486.

95 Kulke MH, Stuart K, Earle CC, et al: A phase II study of temozolomide and bevacizumab in patients with advanced neuroendocrine tumors. J Clin Oncol 2006;24:Abstr.

96 Kunz PL, Kuo T, Kaiser HL, et al: A phase II study of capecitabine, oxaliplatin, and bevacizumab for metastatic or unresectable neuroendocrine tumors: preliminary results. J Clin Oncol 2008;26:abstr.

97 Venook AP, Ko AH, Tempero MA, et al: Phase II trial of FOLFOX plus bevacizumab in advanced, progressive neuroendocrine tumors. J Clin Oncol 2008;26:abstr.

98 Kunz PL, Kuo T, Zahn JM, et al: A phase II study of capecitabine, oxaliplatin, and bevacizumab for metastatic or unresectable neuroendocrine tumors. J Clin Oncol 2010; 28:abstr.

99 Strosberg JR, Fine RL, Choi J et al: First-line chemotherapy with capecitabine and temozolomide in patients with metastatic pancreatic endocrine carcinomas. Cancer 2011; 117:268-275. 
100 Grozinsky-Glasberg S, Franchi G, Teng M, et al: Octreotide and the mTOR inhibitor RAD001 (everolimus) block proliferation and interact with the Akt-mTOR-p70S6K pathway in a neuro-endocrine tumour cell Line. Neuroendocrinology 2008;87:168181.

101 Zitzmann K, De Toni EN, Brand S, et al: The novel mTOR inhibitor RAD001 (everolimus) induces antiproliferative effects in human pancreatic neuroendocrine tumor cells. Neuroendocrinology 2007;85:54-60.

102 Yao JC, Phan AT, Chang DZ, et al: Efficacy of RAD001 (everolimus) and octreotide LAR in advanced low- to intermediategrade neuroendocrine tumors: results of a phase II study. J Clin Oncol 2008;26:43114318.

103 Yao JC, Lombard-Bohas C, Baudin E, et al: Daily oral everolimus activity in patients with metastatic pancreatic neuroendocrine tumors after failure of cytotoxic chemotherapy: a phase II trial. J Clin Oncol 2010; 28:69-76.

104 Yao JC, Shah MH, Ito T, et al: Everolimus for advanced pancreatic neuroendocrine tumors. N Engl J Med 2011;364:514-523.

105 Duran I, Kortmansky J, Singh D, et al: A phase II clinical and pharmacodynamic study of temsirolimus in advanced neuroendocrine carcinomas. Br J Cancer 2006; 95:1148-1154.

106 Chiu CW, Nozawa H, Hanahan D: Survival benefit with proapoptotic molecular and pathologic responses from dual targeting of mammalian target of rapamycin and epidermal growth factor receptor in a preclinical model of pancreatic neuroendocrine carcinogenesis. J Clin Oncol 2010;28:4425-4433.

- 107 Terris B, Scoazec JY, Rubbia L, et al: Expression of vascular endothelial growth factor in digestive neuroendocrine tumours. Histopathology 1998;32:133-138.

108 Höpfner M, Baradari V, Huether A, Schofl $\mathrm{C}$, Scherubl H: The insulin-like growth factor receptor 1 is a promising target for novel treatment approaches in neuroendocrine gastrointestinal tumours. Endocr Relat Cancer 2006;13:135-149.

109 Lopez T, Hanahan D: Elevated levels of IGF-1 receptor convey invasive and metastatic capability in a mouse model of pancreatic islet tumorigenesis. Cancer Cell 2002;1:339-353.

110 Wulbrand U, Remmert G, Zofel P, Wied M, Arnold R, Fehmann HC: mRNA expression patterns of insulin-like growth factor system components in human neuroendocrine tumours. Eur J Clin Invest 2000;30: 729-739.

- 111 Furukawa M, Raffeld M, Mateo C, et al: Increased expression of insulin-like growth factor I and/or its receptor in gastrinomas is associated with low curability, increased growth, and development of metastases. Clin Cancer Res 2005;11:3233-3242.
112 Karhoff D, Sauer S, Schrader J, et al: Rap1/ $\mathrm{B}$-Raf signaling is activated in neuroendocrine tumors of the digestive tract and Raf kinase inhibition constitutes a putative therapeutic target. Neuroendocrinology 2007;85:45-53.

-113 Ohike N, Morohoshi T: Immunohistochemical analysis of cyclooxygenase (COX)-2 expression in pancreatic endocrine tumors: association with tumor progression and proliferation. Pathol Int 2001; 51:770-777.

114 Okami J, Nakamori S, Yamamoto H, et al: An immunohistochemical study of cyclooxygenase (COX)-2 expression in endocrine tumors of the pancreas. J Exp Clin Cancer Res 2002;21:569-576.

$\checkmark 115$ Hofer MD, Chang MC, Hirko KA, Rubin MA, Nose V: Immunohistochemical and clinicopathological correlation of the metastasis-associated gene 1 (MTA1) expression in benign and malignant pancreatic endocrine tumors. Mod Pathol 2009;22: 933-939.

116 Baradari V, Huether A, Hopfner M, Schuppan D, Scherubl H: Antiproliferative and proapoptotic effects of histone deacetylase inhibitors on gastrointestinal neuroendocrine tumor cells. Endocr Relat Cancer 2006;13:1237-1250.

117 Cecconi D, Donadelli M, Rinalducci S, et al: Proteomic analysis of pancreatic endocrine tumor cell lines treated with the histone deacetylase inhibitor trichostatin A. Proteomics 2007;7:1644-1653.

118 Lindberg D, Hessman O, Akerstrom G, Westin G: Cyclin-dependent kinase 4 (CDK4) expression in pancreatic endocrine tumors. Neuroendocrinology 2007;86:112118.

119 Borka K, Kaliszky P, Szabo E, et al: Claudin expression in pancreatic endocrine tumors as compared with ductal adenocarcinomas. Virchows Arch 2007;450:549-557.

120 Hansel DE, House MG, Ashfaq R, Rahman A, Yeo CJ, Maitra A: MAGE1 is expressed by a subset of pancreatic endocrine neoplasms and associated lymph node and liver metastases. Int J Gastrointest Cancer 2003;33:141-147.

$121 \mathrm{Hu}$ W, Feng Z, Modica I, et al: Gene amplifications in well-differentiated pancreatic neuroendocrine tumors inactivate the p53 pathway. Genes Cancer 2010;1:360368.

122 Pitt SC, Chen H, Kunnimalaiyaan M: Inhibition of phosphatidylinositol 3-kinase/Akt signaling suppresses tumor cell proliferation and neuroendocrine marker expression in GI carcinoid tumors. Ann Surg Oncol 2009;16:2936-2942.
123 Ghayouri M, Boulware D, Nasir A, Strosberg J, Kvols L, Coppola D: Activation of the serine/theronine protein kinase Akt in enteropancreatic neuroendocrine tumors. Anticancer Res 2010;30:5063-5067.

124 Djokovic D, Trindade A, Gigante J, et al: Combination of Dll4/Notch and EphrinB2/EphB4 targeted therapy is highly effective in disrupting tumor angiogenesis. BMC Cancer 2010;10:641.

125 Anthony L, Chester M, Michael S, O’Dorisio TM, O'Dorisio MS: Phase II open-label clinical trial of vatalanib (PTK/ZK) in patients with progressive neuroendocrine cancer. J Clin Oncol 2008;26:abstr.

126 Tolcher AW, Sarantopoulos J, Patnaik A, et al: Phase I, pharmacokinetic, and pharmacodynamic study of AMG 479, a fully human monoclonal antibody to insulin-like growth factor receptor 1. J Clin Oncol 2009; 27:5800-5807.

127 Atzori F, Taberno J, Cervantes A, et al: A phase I, pharmacokinetic (PK) and pharmacodynamic (PD) study of weekly (qW) MK-0646, an insulin-like growth factor-1 receptor (IGF1R) monoclonal antibody (MAb) in patients (pts) with advanced solid tumors. J Clin Oncol 2008;26:abstr.

128 Hidalgo M, Tirado Gomez M, Lewis N, et al: A phase I study of MK-0646, a humanized monoclonal antibody against the insulinlike growth factor receptor type 1 (IGF1R) in advanced solid tumor patients in a $\mathrm{q} 2 \mathrm{wk}$ schedule. J Clin Oncol 2008;26:abstr.

129 Reidy DL, Hollywood E, Segal M, Saltz L: A phase II clinical trial of MK-0646, an insulin-like growth factor-1 receptor inhibitor (IGF-1R), in patients with metastatic welldifferentiated neuroendocrine tumors (NETs). J Clin Oncol 2010;28:abstr.

130 Rodon J, Patnaik A, Stein M, et al: A phase I study of q3W R1507, a human monoclonal antibody IGF-1R antagonist in patients with advanced cancer. J Clin Oncol 2007; 25:abstr.

131 Tolcher AW, Yap TA, Fearen I, et al: A phase I study of MK-2206, an oral potent allosteric Akt inhibitor (Akti), in patients (pts) with advanced solid tumor (ST). J Clin Oncol 2009;27:abstr.

132 Piekarz R, Luckenko V, Draper D, et al: Phase I trial of romidepsin, a histone deacetylase inhibitor, given on days one, three and five in patients with thyroid and other advanced cancers. J Clin Oncol 2008; 26:abstr.

133 Trarbach T, Drevs J, Strumberg D, et al: A phase I, open-label, multicenter study of cediranib and AZD0530 in patients with advanced solid tumors. J Clin Oncol 2008; 26:abstr.

134 Chan JA, Ryan DP, Fuchs C, et al: Phase I study of pasireotide (SOM230) in combination with everolimus (RAD001) in patients (pts) with advanced neuroendocrine tumors (NET). 2010 Gastrointestinal Cancers Symposium, Orlando, 2010. 